\title{
Introduction: The Context for the Reform of Labor Law
}

\author{
Sheldon Friedman, Richard W. Hurd, \\ Rudolph A. Oswald, and Ronald L. Seeber
}

The American system of collective bargaining is at a crossroads. Practitioners, academics, and policy makers are scrutinizing the U.S. method of workplace representation and the legal and institutional framework that undergird it and are questioning its capacity to protect workers' rights, to promote industrial peace, and to serve the economic interests of the United States. Some proponents of change focus on the failure of the system to deliver on the Wagner Act's fundamental promise that workers "shall have the right to selforganization, to form, join, or assist labor organizations, to bargain collectively through representatives of their own choosing, and to engage in other concerted activities for the purpose of collective bargaining or other mutual aid or protection." In the interests of increasing productivity and enhancing competitiveness, others propose modifying the framework for collective bargaining so as to promote labor-management collaboration more directly.

The time has come to raise public awareness about the seriousness of these problems and to initiate a wide-ranging national discussion that will lead to the formulation and implementation of badly needed reform. The last such national debate occurred in 1978, more than sixteen years ago, and ended in gridlock and inaction, despite the willingness of a substantial majority in the Congress to support modest but important changes. If anything, the same problems addressed in that debate are more pervasive now, and, in the meantime, new and significant issues have arisen.

It has become increasingly clear that the U.S. system of collective bargaining is no longer a realistic option for a large and growing proportion of American workers, and the situation will continue to worsen absent a major redirection of public policy. The decline in union density rates in this country is alarming to those who value and promote unionization. The extent to which this decline is due to management resistance and the failure of the law to promote collective bargaining is an important question that requires continued study and debate. Opinion polls reveal that for millions of nonunion American workers, workplace representation is an unfulfilled goal. 
These and other concerns about the inadequacy of U.S. labor law motivated the Clinton Administration to create the Commission on the Future of Worker-Management Relations, chaired by John Dunlop and charged with examining the laws that govern and shape relations in America's workplaces. In the same spirit, the Department of Economic Research of the AFL-CIO and the School of Industrial and Labor Relations at Cornell University convened a conference on labor law reform in October 1993. Nearly forty papers and speeches advanced a variety of ways to correct the inadequacies in our system of union-management regulation.

This volume contains a selection of the papers from that conference, chosen to reflect the diversity of opinion and thought represented. While all of the views and policy recommendations expressed in the papers are not necessarily fully shared by the editors, the AFL-CIO, or Cornell, they are stimulating and provocative and deserve the widest possible discussion and debate. Our aim in producing this book is to stimulate public awareness about the need for fundamental reform of the legal and institutional underpinnings of the U.S. system of workplace representation and to offer proposals for the content of that reform.

All of the discussion that follows proceeds from the widely held view that collective bargaining between employers and the unions of their employees is a valuable institution worthy of promotion and dissemination. Of necessity, a well-functioning collective bargaining system requires a strong and independent labor movement. The clear preference of the editors and of the vast preponderance of the authors, therefore, is to find a means of strengthening the law so as to extend collective bargaining in the U.S. economy.

A few facts drawn from the papers highlight key concerns that were addressed at the conference. Dorothy Sue Cobble estimates that more than half of women workers are excluded from coverage under the National Labor Relations Act (NLRA). This reflects changes in both the economy and the employment relationship that have resulted in millions of American workers being stripped of the right granted under the act to choose independent workplace representation.

Kate L. Bronfenbrenner found that 75 percent of employers actively oppose unionization of their workforces. And nearly every antiunion device an employer uses, whether legal or illegal, has a measurable negative effect. Phil Comstock and Maier B. Fox, for instance, report that 36 percent of "no" voters in union representation elections explain their vote as a response to management pressure, and 86 percent of those mention fear of job loss specifically. This was perhaps the most consistent theme at the conference-the right of U.S. workers to organize and bargain collectively has become increasingly limited as a result of widespread employer practices, allowed by law and underregulated by the National Labor Relations Board (NLRB) and the courts. 
Contrary to the concerns of some observers, researchers have found that the restrictions on company-dominated unions (Section 8(a)(2) of the Wagner $\mathrm{Act}$ ) in no way limit labor-management cooperation. In fact, as James Rundle concludes, management violations of Section 8(a)(2) are nearly always associated with other antiunion activity. In 97 percent of the fifty-eight NLRB decisions involving 8(a)(2) violations since 1972, management either was found guilty of committing additional unfair labor practices or to have established the company union in direct response to a union organizing campaign.

Workers should not be denied the freedom to associate, to form and join organizations under their own control and of their own choosing, any more than African-Americans or other minorities should be denied their civil rights or women equal rights. Yet this basic right of U.S. workers has been in great peril in recent years. It is important that, through organizations of their own creation and control, workers deal with their employers as equals. Without such equality, society ultimately suffers.

The papers in the chapters that follow touch upon many subjects. We have attempted to group them in a way that provides ease of access to papers on a single subject while, at the same time, reflecting the scope of necessary labor law reform. Although many might quibble with the appropriate placement of an individual essay, it should be apparent that we have provided a representative sampling of papers that deal with all the important questions and debates.

The first section of the volume, "Historical Perspectives," provides the background necessary to understand the nearly sixty-year history of our current system of labor law. The second and third sections focus on specific aspects of the National Labor Relations Act. The second section, "Organizing and the Law," contains four papers that address the experiences of workers, unions, and managers during organizing campaigns. The third section, "Reforming the NLRA," addresses issues related to the reform of the conduct of collective bargaining. The fourth section, "The Outcomes of Bargaining Relationships," offers a look at several key economic and social benefits of collective bargaining and unionism. The fifth section, "Comparative Perspectives," draws upon experiences of other industrialized nations, particularly Canada. The sixth and final section, "Frameworks for Change," provides alternative views of the overall goals of labor law reform and the means by which to achieve them. The rest of this introduction provides a more detailed description of each of the sections and the papers contained therein.

The stage is set, in the first section of the volume, by Joel Rogers, David Brody, and James A. Gross, respectively. Rogers argues that changes in the United States and the global economy have made the U.S. legal and institutional framework for workplace representation increasingly outmoded and ill 
suited to contemporary economic realities. He advocates the development of a new framework that would provide minimum standards of workplace representation for all workers and a wider array of forms of representation.

Rogers advocates placing these reforms in a broader context of improvements in the "social wage" and a new international trading regime based on observance of labor standards and respect for workers' rights, enforced by a calibrated system of social tariffs. He sees the labor movement as the principal agent for achieving this ambitious and far-reaching program, but for that to happen, labor would have to once again become a mass social movement.

Brody describes and analyzes the history of the U.S. system of workplace representation, which culminated in the passage of the Wagner Act in 1935. Most important, the essay draws lessons from this historical experience that are relevant to today's labor law reform debates. Brody examines how the Wagner Act's strict prohibition against employer domination of labor organizations demonstrated a clear choice between alternative frameworks for workplace representation and a clear rejection of the national experiment with corporatism under the National Recovery Administration, prior to the adoption of the Wagner Act.

Gross calls attention to the conflicting statements of purpose in the TaftHartley Act and argues convincingly that, as a result, much of the original intent of the Wagner Act has been frustrated. The situation has been worsened by the extreme politicization of the NLRB and substantial intervention into labor policy by the judiciary. The core issues underlying national labor policy, according to Gross, are fundamentally moral and ethical, not legal, economic, or competitive. He advances a powerful case in support of the proposition that there should be an underlying moral basis for U.S. labor policy.

The second group of essays address the current state of workers' rights to organize under current law. Richard W. Hurd and Joseph B. Uehlein report on a survey on union organizing undertaken by the AFL-CIO's Industrial Union Department. Their essay summarizes 19 case studies that are broadly representative of the 213 that were submitted by twenty-one unions. These cases document widespread and often abusive employer opposition to union organizing efforts. Although much of this behavior is illegal, the enforcement and penalties are so weak that they do not deter the widespread violations the authors document.

Management consultants have become so bold and so contemptuous of the weakness of the labor law that repeat violations are common, even after their clients are found guilty of unfair labor practices and are required to post "cease and desist" orders. In one particularly egregious but telling case, a unionbusting consultant was ordered to post a cease and desist order seven years after a representation election that was found to be tainted by his extensive unfair labor practices; he posted the notice on the seat of his employees' toilet. 
Bronfenbrenner reports on a major survey of union organizers. She also found that employer opposition was widespread and often effective in thwarting organizing. Fully 70 percent of employers used a management consultant for their campaigns, and an additional 15 percent used an outside law firm. Overall, more than 75 percent of employers conducted active antiunion campaigns. Tactics used included discharges, captive audience meetings, supervisor one-on-ones, wage increases, promises of improvements, promotion of union leaders, antiunion committees, small-group meetings, letters, and leaflets. Lower union win rates were associated with most of these tactics. Stipulated or board-ordered units that were different from units requested in the petition also had a negative impact on election outcomes.

Comstock and Fox draw on the more than 150,000 telephone interviews the Wilson Center for Public Research has conducted over the last fourteen years of nonunion workers. Based on these interviews, they acknowledge a decline in interest in unionization during the late 1970s and early 1980s but report that worker interest has increased appreciably since then. Women, minority, and younger workers, in particular, make up a large and fastgrowing segment of the labor force that is substantially more interested in unionization today than ten years ago. Comstock and Fox suggest that the continuing decline in union density may thus be the result not of a lack of interest in unionization by workers but of the escalating use by employers of aggressive union-avoidance tactics.

The use of these tactics has been especially pronounced, and is especially effective, in frustrating organizing in workplaces where workers want and need unions the most: in firms where job satisfaction is low, where the desire for unionization is high, and where there are high concentrations of women, minority, or less skilled workers. Comstock and Fox conclude that one important explanation for the wide gap in union density between the United States and nearly every other industrial country is the extent to which U.S. employers are allowed to campaign actively and aggressively to prevent their employees from achieving independent collective representation.

Gordon R. Pavy's essay reports on the results of a major survey by the AFL$\mathrm{CIO}$ and its Industrial Union Department on the degree of difficulty unions experience in obtaining first and subsequent collective bargaining agreements after victories in NLRB representation elections. Of all the election victories by unions in 1987, for example, first contracts were not achieved a third of the time and only about half the units involved in these victories were still under contract in 1993. Pavy's essay underscores the urgent need for reforms to protect the right of workers to collective bargaining even after union certification has been achieved.

The third set of papers-by Robert J. Pleasure and Patricia A. Greenfield, Morris M. Kleiner, Robert B. Moberly, James R. Rundle, and Gladys W. Gruenberg - address specific proposals for reforming the NLRA. Pleasure 
and Greenfield's essay makes the case that comprehensive proposals for labor law reform should be developed through a nonpartisan process similar to the one that led to the development of the Uniform Commercial Code (UCC). Such a process would involve reviewing not only labor law as it is narrowly defined but all aspects of employment and corporate law that impinge on workers as they strive to gain a measure of democratic control over their working lives. A narrower approach that focuses on specific deficiencies of labor law, it is argued, trivializes and understates the depth of worker and union dissatisfaction with the current framework. Viewed from this perspective, the work of the Dunlop Commission is a beginning, not an end. Pleasure and Greenfield emphasize, however, that the approach they are recommending is not an excuse for inaction or delay; urgently needed reforms should be adopted promptly and do not require waiting for the results of the longerterm, comprehensive review they are advocating.

Kleiner documents the skyrocketing increase in managerial violations of the NLRA, which he argues is attributable primarily to the weakness of the penalties for these violations under current law. He surveys the empirical literature on the relationship between the penalties and deterrence of violations by management and concludes that even increasing the penalty to no more than the average union wage in the potential bargaining unit would deter up to 29 percent of serious violations. The essay presents a range of policy options to effectuate improved management compliance with the law.

Complementary essays by Moberly and Rundle, respectively, address the important debate about the relationship between the NLRA's prohibition against employer-dominated labor organizations and the goal of promoting the new methods of work organization that are required by so-called highperformance workplaces. A number of government officials, academics, and management practitioners have raised concerns, in the wake of the recent Electromation and $D u$ Pont decisions, that the NLRA's ban is or will become an impediment to the development of high-performance workplaces and thereby undermine the nation's economic comperitiveness. Moberly examines the facts of the Electromation and $D u$ Pont cases and concludes, after extensive analysis, that they do not support repeal or weakening of the ban on employer domination of labor organizations; quite the contrary, these cases underscore the continued need for the ban.

Rundle reaches a similar conclusion by a different route. His essay reports on empirical research centering on a comprehensive search for and review of every case since 1972 in which the NLRB ordered the disestablishment of an employee committee on grounds of employer domination. Relatively few disestablishment orders were found, and the number of such orders has been declining in recent years, despite the proliferation of workplace committees. More important, Rundle did not find a single instance in which a disestablishment was ordered in the absence of one or more of the following facts: (1) 
the employer in question committed one or more other unfair labor practices concurrently with the $8(\mathrm{a})(2)$ violation, including interrogations, threats, surveillance, discharge for union activity, and refusal to bargain; (2) the employer started the committee in response to a union organizing drive; or (3) the committee, by the employer's own admission, had nothing to do with quality, productivity, or worker empowerment. Rundle therefore concludes that there is not a single case of this type that demonstrates the need to relax or modify the prohibition against employer domination.

Legislative proposals to improve employer compliance with the duty to bargain, broadly, is the focus of Gruenberg's essay. She argues that the promise of the employer's duty to bargain is not insubstantial even under current law but that weak enforcement and inadequate penalties seriously undercut delivery on that promise. She proposes a series of specific legislative remedies to foster and promote true collective bargaining, in deed as well as in name. Among these is a proposal to eliminate the judicially imposed distinction between mandatory and permissive subjects of bargaining, an unlegislated legalism that has prevented workers from achieving redress through collective bargaining to a large and growing number of pressing workplace problems.

The fourth group of essays focuses on three important social and economic dimensions of trade unionism: (1) the special importance of trade unionism to women and minority workers and the related role of unions in narrowing the male-female earnings gap; (2) the role of trade unionism in promoting the development of a skilled workforce by encouraging investments in worker training and skill upgrading; and (3) the potential importance of unions in facilitating the application of technology and other workplace innovations in ways that are socially responsible and economically desirable.

The essay by Roberta Spalter-Roth, Heidi Hartmann, and Nancy Collins asks and answers the question "What do unions do for women?" Based on extensive, original data analysis, the authors conclude that unions are of special importance in raising the earnings of women and minority workers and of all workers with low job tenure and in reducing the gap in their earnings relative to those of older white male workers. Unions reduce wage disparities overall by raising the wages of those at the bottom of the earnings spectrum the most. Unions also raise wages the most for those workers who are the least educated and who have worked the fewest years on the job. Thus, a good way to raise wages for women, minority, and less educated workers, and to create a more equal distribution of income in the United States, would be to increase union density and collective bargaining coverage.

Unions also play an important role in skill formation and training, as the essay by Hamid Azari-Rad, Anne Yeagle, and Peter Philips makes clear. This essay presents a case study of the impact of the repeal of Utah's prevailing wage law. The authors found that the repeal accelerated the decline in the union share of Utah's construction labor market, drove down construction 
wages in the state, and reduced the resources available for union apprenticeship training in construction. This decline in training has not been offset by any other public or private source and has been exacerbated by the exit of experienced construction workers from the industry. The repeal of Utah's prevailing wage law, the authors therefore conclude, has led to a market failure in training and to a looming crisis in training for construction workers in Utah.

Charley Richardson argues that technology is radically transforming the workplace. The resulting changes cannot be counted on to be socially or economically beneficial in the absence of a strong independent voice for workers, through their unions. Far from encouraging such voice, current labor law is a serious impediment to it. The distinction between so-called mandatory and permissive subjects of bargaining, in particular, often prevents unions from addressing çritical issues of workplace technology in a serious way. Technology is also altering the balance of power in the workplace, weakening the power of workers and their unions in ways that the framers of the Wagner Act could not have imagined, while underscoring the urgent need for labor law reform.

The fifth group of essays addresses labor law reform from a comparative perspective. Three-those by Gary N. Chaison and Joseph B. Rose, Richard N. Block, and Peter G. Bruce-look north to Canada; the fourth essay, by Roy J. Adams, examines Western Europe. Each seeks to draw conclusions from experiences elsewhere and considers their implications for labor law reform in the United States.

Chaison and Rose explain that there is no single Canadian model, since the regulation of labor relations takes place primarily at the provincial level in Canada. But, despite the resulting diversity, there is a common theme: Workers are provided with a more unfettered right to choose unionism than in the United States, even if this right requires substantial government intervention in labor-management relations. It has been suggested that the protection in most Canadian provinces of workers' right to organize compels protection of their right to secure a first collective agreement and their right to strike without fear of losing their jobs to newly hired replacements. As Chaison and Rose note, the issue in Canada is not whether the playing field is "level" between labor and management but rather that workers' rights must be protected. This, they suggest, is reason enough to take a hard look at our neighbor to the north as a model for U.S. labor law reform.

Bruce's essay complements Chaison and Rose's by comparing the administration of labor law by the NLRB and by the Ontario Labor Relations Board with respect to unfair labor practices. He argues that the differences in labor law and its administration account for a substantial part of the large gap in union density between Canada and the United States. Bruce finds a much higher incidence of employer unfair labor practices in the United States than 
in the most populous and industrialized Canadian province. He attributes this difference to the relative weakness of the remedies available under U.S. law and to the more vigorous and effective regulation of employer misconduct in Ontario. He recommends specific reforms to strengthen the regulation of employer misconduct in the United States.

Identifying the key institutional differences between the U.S. and Canadian frameworks for workplace representation is the focus of Block's paper. These differences have the effect of disadvantaging workers and their unions, systematically and substantially, in the United States, according to Block. The resulting power relationships between employers, on the one hand, and workers and their unions, on the other, are very different in Canada than in the United States. Based on his comparison, Block concludes with a series of specific recommendations for labor law reform in the United States.

Adams's essay shifts the focus to Western Europe, where, it is noted, the presumption in most countries is that workers should have workplace representation as a basic right. In Adams's view, this presumption is entirely proper and, indeed, essential to the achievement of political and economic democracy. In the United States, by contrast, there is no such presumption. Rather, a small and decreasing proportion of the workforce enjoys the right to workplace representation. Workers who do not now have this right and who seek to assert it can do so only at great personal risk and heavy cost, and they must overcome intense and widespread employer opposition. In contrast to the Western European presumption in favor of workplace democracy, the presumption in the United States is in favor of workplace autocracy. Adams argues that instead of tinkering at the margins with reforms that at best would make it easier for a small proportion of the workforce to struggle successfully for workplace democracy, there should be systemic reform to guarantee workplace democracy for all.

The volume concludes with three essays that set forth alternative frameworks and principles for fundamental change in the system of workplace representation. Included are essays by Dorothy Sue Cobble, Howard Wial, and Françoise J. Carré, Virginia duRivage, and Chris Tilly.

Cobble and Wial specify the ways in which workforce and workplace changes require a new framework for workplace representation. Cobble calls attention to the large and growing proportion of workers in the postindustrial workplace who are women or minority members. Many of these workers, as well as many white male workers, would be better served by a model of unionism more reminiscent of the occupational unionism that dominated before the rise of industrial unionism in the 1930s. A variety of legal and institutional obstacles, however, make it difficult for this form of trade unionism to take hold and spread. Cobble enumerates the obstacles and offers specific policy recommendations to remove them and to encourage the development of a new occupational unionism. 
Wial examines the tidal wave of corporate restructurings, the rise in subcontracting and interfirm alliances, the decrease in job security, and the implications of all of these trends for union organizing, collective bargaining, and the employment relationship. He suggests that trade unions should rely increasingly on multiemployer organizing and multiemployer collective bargaining as partial responses to these trends. He also describes the significant legal and institutional disincentives to multiemployer bargaining and organizing and suggests that the elimination of these disincentives, and their replacement with several specific positive incentives for multiemployer bargaining and organizing, should be included among the goals of labor law reform.

The final essay in the volume, by Carré, DuRivage, and Tilly, reviews the rise of contingent employment and addresses the implications of this trend for union organizing. Limitations of current labor law effectively disenfranchise this large and growing component of the workforce from access to independent collective representation. The essay details the specific deficiencies of current employment and labor law in this regard and provides specific recommendations for reform.

As this volume goes to press, there is reason to be hopeful that its essential message will be helpful in informing a critical and long-overdue public policy debate. Recent stirrings create new possibilities for positive change in the U.S. system of workplace representation. President Clinton's election in November 1992 and the subsequent appointment by the secretaries of labor and commerce, in March 1993, of the Commission on the Future of WorkerManagement Relations, chaired by John Dunlop, is a significant and noteworthy step.

Although the focus of the commission is primarily economic competitiveness and productivity, it is clearly within its realm and charge to consider the issues raised in this book. For those who value a strong and independent trade union movement as a hallmark of an advanced economic democracy, the commission could offer some hope. Whether that hope will be matched by significant labor law reform remains an open question. For those who believe that collective bargaining is a system deserving of the widest possible use, the possibility of reform looms as a positive possibility. If this volume makes a contribution to public discussion that leads to the accomplishment and advancement of those goals, we will have achieved our immodest aims. 